\title{
Exportação de democracia na política externa norte- americana no pós-Guerra-Fria: doutrinas e o uso da força
}

\author{
Exporting of democracy in American foreign policy in the \\ post-Cold War period: the doctrine and the use of force
}

MARIA HELENA DE CASTRO SANTOS*

Rev. Bras. Polít. Int. 53 (1): 157-191 [2010]

\section{Introdução ${ }^{1}$}

Em tempos de invasões militares no Oriente Médio em nome da democracia, exportação de democracia se torna tema de grande relevância nas Relações Internacionais, tanto da perspectiva acadêmica como do ponto de vista das doutrinas da política externa do hegemon.

Há pouco mais de 35 anos atrás, Packenham (1973), baseado em Hartz (1955), nos ensinou que as doutrinas de política externa elaboradas pelos tomadores de decisão e as teorias produzidas pelos cientistas sociais americanos em relação aos países em desenvolvimento compartilhavam o mesmo corpo de idéias centrais, fortemente normativo, baseado em premissas que ele chamou de tradição liberal americana. Packenham analisou as doutrinas de ajuda externa aos países do Terceiro Mundo e a literatura (teoria da modernização) referente ao desenvolvimento político destes países, no período 1947-1968. De maneira equivalente, é possível mostrar que a literatura de democratização da $3^{\text {a }}$ Onda de Democracia (Huntington, 1991) e as doutrinas de política externa do hegemon voltadas para a difusão da democracia no pós-Guerra Fria também compartilham um mesmo corpo de conceitos, princípios e valores, baseado igualmente na tradição liberal americana.

Este artigo, contudo, por questōes de tempo e espaço, focalizará, sobretudo, os pilares das doutrinas de política externa americana, mirando um aspecto

\footnotetext{
* Professora do Instituto de Relaçōes Internacionais da Universidade de Brasília - UnB e pesquisadora do Conselho Nacional de Desenvolvimento Científico e Tecnológico - CNPq (mhcastrosantos@gmail.com).

1 Este trabalho é um produto parcial de pesquisa mais ampla que contou com o apoio do CNPq e da FINATEC/UnB, coordenada pela autora, tendo como assistente de pesquisa Ulysses Tavares Teixeira. Contou também com um grupo de bolsistas PIBIC que foram se sucedendo: Carolina Vieira de Simone, Rafael Alonso Veloso, Lucas José Galvão Garcia de Freitas, Heitor Ferreira Sobral Torres, Milena Teixeira Santos, Felipe Ricardo Baptista e Silva, Ricardo Zanata Bortolli e Mateus Drumond Caiado e, em sua etapa final, teve a colaboração dos bolsistas Ludmila Yuki Sumizono Vieira, Wilson Tadashi Muraki Junior e Larissa Paranhos Meireles. De maneira inteiramente voluntária colaboraram os alunos Jonas Paloschi e Germano Araújo Coelho.
} 
específico: o lugar que aí ocupa democracia e sua relação com segurança. Mais especificamente, buscam-se as bases da doutrina da política externa americana que justificam a exportação de democracia, mesmo que pelo uso da força - o meio mais difícil de ser usado em nome da democracia. Deixa-se para uma próxima comunicação o exame sistemático do corpo de conceitos básicos e vieses normativos em que se apóia a literatura de democratização da $3^{\text {a }}$ Onda.

O exame dos pilares das doutrinas de política externa será feito pela análise de conteúdo, quantitativa e qualitativa, dos discursos dos Presidentes e seus Secretários de Estado, cobrindo-se o período do pós-Guerra Fria. Os resultados são ainda parciais, já que ficaram de fora da análise os discursos dos Secretários de Defesa. Acredita-se, contudo, que as tendências gerais já estejam bem delineadas. A administração de George H.W. Bush, contudo, não será aqui examinada com propriedade, já que os discursos do seu Secretário de Estado não estão disponíveis. O prejuízo analítico pode, no entanto, ser considerado como se fora uma decisão metodológica acertada, já que este governo tem sido considerado, por suas características, ainda uma administração da guerra-fria. Para Cameron (2005), por exemplo, Clinton foi o primeiro Presidente do pós-Guerra Fria. Ainda assim, os discursos do Bush pai serão levados em conta quando apropriado.

A segunda seção do artigo procede à contagem das ocorrências da palavra democracia e derivadas vis-à-vis da palavra segurança e afins nos discursos dos Presidentes e seus Secretários de Estado. A terceira seção analisa qualitativamente os discursos selecionados e identifica os princípios justificadores da exportação de democracia da política externa americana no período em análise.

\section{Democracia e segurança na política externa americana do pós-Guerra Fria}

Apresentam-se nesta seção os resultados quantitativos da análise de discursos selecionados dos Presidentes americanos e seus Secretários de Estado ${ }^{2}$ na nova era inaugurada após a derrocada da União Soviética. Ao todo foram analisados 415 discursos, sendo 94 presidenciais e 321 dos Secretários de Estado.

Estamos no período do pós-Guerra Fria. Sem grandes ameaças aparentes, os Estados Unidos podem basear sua doutrina de política externa nos princípios da democracia, sem as ambigüidades da guerra fria. Interessa, assim, saber a importância que democracia ocupa na política externa deste período, comparando-a com segurança, preocupação maior na guerra fria.

2 Os discursos selecionados dos Secretários de Estado norte-americanos foram proferidos na ONU, OTAN e Congresso dos Estados Unidos. Fonte: Departamento de Estado dos Estados Unidos, www.state.gov. A fonte dos discursos dos Presidentes americanos é o seguinte site da Universidade de Santa Bárbara: http:// www.presidency.ucsb.edu. Foram analisados todos os discursos dos seguintes grupos: the State of the Union; Grandes Discursos para a Nação; Mensagens Orais ao Congresso, Discursos Inaugurais, discursos formadores da Doutrina Bush. 
O exame das Tabelas I e II demonstram que apesar da ameaça do mundo comunista ter desaparecido, a preocupação com segurança permaneceu ocupando espaço muito importante na política externa americana. De fato, o número de vezes em que a palavra democracia e suas correlatas são pronunciadas pelos Presidentes da guerra-fria, 1128, não chega a ser $1 \%$ maior que o número de vezes em que a palavra segurança e equivalentes são ditas, 1111. No caso dos discursos dos Secretários de Estado, a ocorrência da palavra segurança e intercambiáveis, 3101, superam em quase $9 \%$ a da palavra democracia e correlatas, 2603, sendo Warren Christopher o Secretário que mais claramente contribui para este resultado.

Quanto à importância de democracia, se ela pouco superou o espaço dedicado à segurança nos discursos dos Presidentes, ela o fez, segundo alguns autores, de modo menos ambíguo. Vimos que este não foi o caso dos Secretários, os quais em geral dão mais ênfase à segurança. A grande exceção fica por conta de Condoleezza Rice. De fato, como o exame das Tabelas I e II e dos Gráficos I e II demonstram, há um pico do uso da palavra democracia a partir de 2005 em seus discursos, justamente quando a Secretária é empossada. De fato, a palavra democracia e derivadas superam em cerca de $10 \%$ o vocábulo segurança e equivalentes nos discursos analisados de Rice. Isso ocorreria também nos discursos de Bush. Estes usam apenas cerca de $2 \%$ a mais de palavras relacionadas à segurança em sua primeira administração, enquanto na $2^{\text {a }}$ administração a palavra democracia e correlatas são quase $20 \%$ mais utilizadas do que segurança e afins.

Não haveria aí uma inconsistência do governo Bush? O grande evento marcante da sua administração foram os ataques simultâneos às torres gêmeas em Nova York e ao Pentágono, alguns meses depois do seu início. Poderia se esperar que nessas circunstâncias a preocupação com segurança predominasse sobre todas as demais, predominância que só apareceu nos discursos de Colin Powell. Estes registram $27 \%$ a mais de ocorrências da palavra segurança e afins do que de democracia e correlatas. Sabe-se, por outro lado, que ao contrário de Powell, Condoleezza Rice foi uma das mentoras da chamada Doutrina Bush, uma dura resposta aos ataques do 11 de setembro que incluía guerra preventiva contra grandes ameaças percebidas, unilateralismo quando necessário e papel proeminente e agressivo dos Estados Unidos no mundo para garantir paz e estabilidade. Não haveria uma contradição entre a ênfase posta nos discursos da Secretária e do próprio Presidente em democracia e as bases da Doutrina Bush, em grande parte uma doutrina de defesa nacional?

Para responder à indagação anterior é necessário recorrer-se à análise qualitativa dos discursos dos Presidentes e seus Secretários de Estado, o que será feito a seguir.

\section{Princípios e pilares da política externa americana}

A partir do exame qualitativo de 415 discursos, foi possível identificar empiricamente três princípios que formariam as bases da política externa 
americana. Foi também possível reconhecer claramente uma "missão americana" perante o mundo. São eles:

(1) Os valores e princípios da democracia liberal ocidental são universais, isto é, todos os povos do mundo desejam tornarem-se democráticos. Portanto, a promoção da democracia é para o bem da humanidade.

(2) Democracias não lutam entre si. Portanto, exportar democracia significa promover a paz mundial. Aqui democracia é ligada à segurança global.

(3) A promoção da democracia faz o mundo mais seguro e mais próspero para os Estados Unidos. Aqui democracia é ligada à segurança e aos interesses americanos. Missão: Os americanos estão imbuidos de uma missão perante a humanidade: trazer-lhe liberdade e democracia.

Perceba-se, de imediato, a ligação inequívoca que os princípios dois e três trazem entre democracia e segurança, não só segurança global, mas a própria segurança dos Estados Unidos, sem falar em seus interesses econômicos.

Perceba-se, em seguida, a importância central que a promoção e a exportação da democracia ocupam nos pilares ideológicos da política externa americana. Aqui se coloca a pergunta: quanto pesam as variáveis externas vis-à-vis as internas no processo de democratização? Em outro artigo procuro responder a essa pergunta, concluindo:

(...) pode-se dizer que, em que pese não haver consenso na literatura, pelo menos a partir da democratização dos países comunistas nos anos 1990, a influência das variáveis externas para promover (ou impor) democracia passa a ser reconhecida e aceita, embora em graus distintos. Este é um respaldo acadêmico de grande importância para os formuladores das doutrinas de política externa americana do pós-Guerra Fria. Eles precisam acreditar e convencer a sociedade americana que as intervençôes militares dos Estados Unidos, mesmo que unilaterais, são eficazes no que diz respeito à promoção da democracia. Eles dirão isso em várias ocasiōes, de várias maneiras e em vários discursos." (Castro Santos, 2010a: 17)

Os discursos dos Presidentes e seus Secretários de Estado foram também analisados e classificados de acordo com os princípios identificados acima. As Tabelas III, IV, V e VI descrevem os resultados encontrados, por princípio, separadamente por Presidente e por Secretário de Estado e por cada administração como um todo. As Figuras III, IV, V e VI comparam as 4 administrações examinadas, por princípio, considerando-se a soma dos discursos dos Presidentes com os dos Secretários de Estado, tornando assim os resultados mais significativos.

O exame das Figuras de III a VI mostra, de início, que tanto a missão quanto os três princípios estão presentes nos 4 mandatos dos dois governos. A análise qualitativa dos discursos indica a freqüente utilização dos princípios ligados aos 
problemas específicos enfrentados por cada governo. Por exemplo, queda do mundo comunista, alargamento da OTAN ou ataque aéreo nos Bálcãs nos governos Clinton e terrorismo, invasões do Afeganistão e Iraque nos governos Bush.

Outra constatação importante refere-se às diferentes ênfases atribuídas a cada princípio ao longo das administrações examinadas. A diferenciação não tem a ver com o "governo Bush" ou o "governo Clinton" tomado como um todo homogêneo ou com o partido do Presidente, mas sim com a combinação do Presidente e cada Secretário de Estado. Sendo assim, pode-se notar, grosso modo, maior afinidade entre Clinton-Albright e Bush-Powell e entre Clinton-Christopher e Bush-Rice do que entre as combinaçóes do mesmo governo. Note-se que os primeiros pares enfatizam a universalidade dos princípios democráticos e a missão de levar liberdade e democracia aos povos do mundo, enquanto os segundos pares reforçam os princípios que ligam democracia à segurança - global e nacional - e aos interesses americanos. Observe-se, contudo, que no caso do vínculo da democracia com a segurança e os interesses americanos, pouca diferença de ênfase registra-se nos dois mandatos do governo Bush.

Discute-se, a seguir, cada princípio sugerido da política externa americana, mostrando-se sua utilização em cada administração do período do pós-Guerra Fria.

\section{Primeiro Princípio: os valores e princípios da democracia liberal ocidental são universais}

A crença na universalidade dos princípios da democracia liberal ocidental foi reforçada pela vitória americana na guerra-fria. De fato, tanto tomadores de decisão como cientistas sociais interpretam a vitória americana na guerra fria como a vitória da democracia liberal ocidental sobre o comunismo. Isto é, o sistema de valores, princípios e idéias da democracia teria se provado melhor e superior ao sistema de valores, princípios e idéias comunistas e é por isso que todos os povos do mundo, concluem eles, desejam tornar-se democráticos. Bush pai expressa bem esse sentimento:

The triumph of democratic ideas in Eastern Europe and Latin America and the continuing struggle for freedom elsewhere all around the world all confirm the wisdom of our nation's founders (State of Union, 1991).

Se essa concepção doutrinária teve como respaldo acadêmico as idéias de grande impacto de Francis Fukuyama (1989,1992), estas enfrentariam a não menos importante e influente crítica de Samuel Huntington (1996), que fala de um mundo multicultural, onde clivagens ao longo de linhas culturais e religiosas interpõem fortes obstáculos à democratização em sociedades confucionistas e islâmicas.

Os formuladores das doutrinas da política externa americana no mundo pós-Guerra Fria, contudo, rejeitavam a advertência cultural de Huntington. Eles 
diriam várias vezes em público que todos os povos do mundo desejam tornarem-se democráticos, não reconhecendo incompatibilidades de qualquer natureza com os valores da democracia.

Dos dois governos analisados, o de Clinton é o que menos problemas teria com a tese de Huntington, já que as intervenções militares da sua administração não enfrentariam civilizaçôes consideradas incompatíveis com a democracia por aquele autor.

Assim, Clinton usaria o primeiro princípio como, por assim dizer, o critério de sucesso das intervençôes e acordos de paz nos Bálcãs:

Today, because of our dedication, America's ideals-liberty, democracy, and peaceare more and more the aspirations of people everywhere in the world. It is the power of our ideas, even more than our size, our wealth, and our military might, that makes America a uniquely trusted nation." (Bill Clinton, Address to the Nation on Implementation of the Agreement in Bosnia. Herzegovina, 11/27/1995)

Warren Christopher, Secretário de Estado de Clinton na $1^{a}$ administração, embora seja o Secretário que menos recorreu ao $1^{\circ}$ princípio (cf. Tabela III) em seus discursos, não deixa de assinalar que democracia não é inadequada para a Ásia. Ao contrário, os anseios por mais liberdade não são um produto de exportação ocidental, diz ele: são um instinto humano (Sixth-plus-Seven Open Session of the ASEAN Post-Ministerial Conference, Singapore, July, 1993). De forma mais clara ele diria:

While we recognize that each nation must find its own path, consistent with its own history, we believe that these ideals of the Universal Declaration reflect the values not just of the United States, but of countries and cultures all over the world" (Warren Christopher, The Us \& China: Building a New Era of Cooperation, 1996).

Mas foi Madeleine Albright, que substituiu Christopher no segundo mandato de Clinton, a Secretária que mais referência fez ao primeiro princípio em suas comunicações: quase $60 \%$ dos seus discursos continham referência a esse princípio, correspondendo a $45 \%$ do total dos discursos dos Secretários analisados até aqui que se remetiam de alguma forma à crença americana na eleição universal da democracia como o único sistema político legitimo no mundo (cf. Tabela III). Além de declaraçôes sobre a universalidade dos princípios da democracia, tais como:

In truth, we understand well that democracy, by definition, cannot be imposed. It must emerge from the desire of individuals to participate in the decisions that shape their lives. But this desire is present in all countries [ênfase adicionada] (Statement before the Senate Foreign Relations Committee, Fevereiro 1998). 
ou:

We believe, and the Universal Declaration on Human Rights affirms, that "the will of the people...expressed in periodic elections" should be the basis of government everywhere. We are working actively to promote the observation of this principle around the world (MA Testimony on FY-2000 Budget, Fevereiro 1999).

Albright expressa em vários discursos a crença americana de que os povos das diversas regiōes em que os Estados Unidos, a OTAN e/ou a ONU tiveram que intervir como peace brokers, mereciam auto-governar-se sob regime democrático, algo há muito desejado por eles. A Secretária refere-se nestes termos, por exemplo, a Kosovo, Sérvia, Montenegro, Croácia, Haiti e Ucrânia. ${ }^{3}$

No que se refere ao governo Bush, com certeza não seria possível aceitar a tese de Huntington e ao mesmo tempo tomar a decisão de invadir militarmente e implantar a democracia em dois países islâmicos após os ataques de 11 de setembro. De fato, assim se expressa Bush e seus Secretários:

We also hear doubts that democracy is an unrealistic goal for the greater Middle East, where freedom is rare. Yet it is mistaken and condescending to assume that whole cultures and great religions are incompatible with liberty and self-government. I believe that God has planted in every human heart the desire to live in freedom. And even when that desire is crushed by tyranny for decades, it will rise again (George W. Bush, State of Union, 2004).

Colin Powell, com relação ao Iraque, diz que os Estados Unidos não vão recuar no que se refere ao combate ao terrorismo. Isso seria feito usando-se todos os elementos do poder nacional, mas acima de tudo, seria usado um sistema de valores:

(...) that is still respected around the world, a value system that has fueled this nation for so many hundred of years and is fueling so many other nations around the world, a value system that says democracy works and it is not restricted to western cultures or to the United States" (Colin Powell, Speech at the Institute of Peace on US efforts to assist the people of Iraq, Washington, 2004).

Portanto, ele completa em outro discurso, “There's no reason that democracy can't work in Afghanistan (...)" (Remarks at the Southern Center for International Studies. Atlanta, Georgia, outubro, 2004).

3 Ver os discursos: Statement before the House International Relations Committee, abril, 1999; Op-Ed for USA Today, maio 1999; Press remarks during recess from the UNSC Meeting on the Democratic Republic of Congo, janeiro 2000; Opening Remarks on Fiscal Year 2001 International Affairs Budget before the Senate Foreign Relations Committee, fevereiro, 2000; Intervention at Nato-Ukraine Commission Ministerial, dezembro 2000. 
Da mesma forma, Condoleeza Rice não perde a oportunidade de afirmar a compatibilidade dos princípios democráticos com o Iraque. Considerando as primeiras eleições neste país, ela afirma que o alto comparecimento da população indicava "what we've always known, that democratic principles don't have boundaries, they're not Western values; these are universal values" (interview, ABC, Washington D.C., janeiro, 2005).

Apesar do foco do Governo Bush privilegiar o Oriente Médio após o 11 de setembro, a utilização do primeiro princípio mirava o mundo como um todo. Dessa forma, ao defender o orçamento do Presidente Bush para o ano fiscal de 2003 perante o Congresso, Colin Powell fala de democracia, dos valores universais de liberdade e paz que são, na verdade, os valores de Deus:

All people want the same thing for their children: food on the table, a roof over their head, clothes on their back, schooling, health care, and a hope for a better future for your children. It comes with democracy, it comes with free market economics. An important part of the President's speech which also undergirds our foreign policy was his talk about values in the latter part of the State of the Union speech. Not American values, not European values, not even Islamic values, but universal values of freedom, of peace. God's values, given to each man and woman on earth to pursue their destiny, limited only by their willingness to work, the system in which they are allowed to work, and by their own ambition (Statement on President Bush’s Budget_Request for FY 2003, fevereiro, 2002).

Em 2005, Rice diria, perante a ONU:

(...) when speaking about democracy, the United States has reason for humility. After all, it was only in my lifetime that America guaranteed the right to vote for all its citizens. Obviously, the path to democracy is long, and imperfect, and different for every nation. But the principles of democracy are universal - as is the desire for them. And the United Nations must support every country that embraces the challenge of self-government. In Afghanistan, Iraq, Lebanon, in the Palestinian territories and throughout the world, peoples who want to build democracy deserve our help. (...) It is these institutions that enable citizens of conviction to lead us ever closer to the ideals of justice that stir every soul -- the universal desire for security, and prosperity, and liberty, and dignity (Remarks at the $60^{\text {th }}$ United Nations General Assembly, September 2005).

Nos dois anos seguintes, Rice reafirmaria a natureza não-culturalista da universalidade do sistema de princípios e valores da democracia. Reafirmaria também a disposição dos Estados Unidos de apoiar os "que estão tentando construir sociedades mais livres": 
I want just to note that the budget reflects the President's determination to carry out a policy that is indeed grounded in American values, but values that are not just American values but universal values. That means support for a democracy agenda that supports those in countries across the world who wish to have the freedom and liberty that we enjoy (FY 20007, State Department Budget Request, abril, 2006).

E:

What you do with democracy is to support those who within their own indigenous circumstances are trying to bring about freer societies. (...) It is not a cultural issue; it is a human issue to want to have control of your own life (Remarks at the Young Global Leaders Policy Roundtable. Washington DC, April 19, 2007)

Note-se que a insistência de Rice no apoio Americano a todos os países que estiverem tentando se democratizar é muito apropriada para a política externa americana, desenhada após os ataques de 11 de setembro. De fato, recorde-se que a Doutrina Bush previa um protagonismo americano muito maior do que ocorrera nos meses anteriores aos ataques terroristas a Nova York e Washington, exportando democracia como a melhor arma de defesa contra o terrorismo.

Interessante notar também que não há menção às invasões militares do Afeganistão e do Iraque nos discursos dos dois Secretários: nem nos exemplos aqui apontados e nem nos demais discursos selecionados por conterem referências à universalidade dos princípios democráticos. Na retórica do primeiro princípio, tudo se passa como se o hegemon tivesse indo de encontro ao desejo dos povos iraquiano e afegão, há muito sufocados por ditaduras do mal. Na verdade, há a crença de que se aos povos submetidos a ditaduras for dada a chance de se manifestarem eles certamente escolherão viver sob uma democracia. ${ }^{4}$

\section{Princípio 2: Democracias não lutam entre si}

A tese de que democracias não lutam entre si deriva da proposição kantiana de acordo com a qual repúblicas - porque são formas puras de governo - oferecem as melhores condiçõoes para a emergência de paz duradoura entre as nações. Esse tem sido o aspecto relativo à democracia que mais tem concentrado as atençóes dos estudiosos de Relações Internacionais. A literatura de referência oferece mais de um tipo de explicação para essa tese (Russett, 1993; Starr, 1992; Rummel, 1983), que tem sido contestada de vários ângulos (Mearsheimer, 1990; Kegley and Hermann, 1996; Layne, 1994). Sua validade, contudo, é muito bem aceita pela academia em geral e políticos americanos.

4 Cf. George W. Bush, State of the Union, janeiro 2008; George H. W. Bush, State of the Union, 1989; Condoleezza Rice, interview ABC, Washington D.C., janeiro, 2005; Madeleine Albright, discursos, ver pé de página no 8 . 
Assim, o princípio da paz democrática tem sido largamente usado para justificar a defesa da democracia, se necessário pelo uso da força, prevista inclusive pelas cartas da ONU, da OEA e outras Organizações Regionais. O mundo democrático é estável e seguro e, portanto, serve aos interesses da humanidade. $\mathrm{Na}$ era do pós-Guerra Fria estas assertivas pareceriam mais consistentes do que nunca.

A crença na paz kantiana esteve, assim, presente nos discursos que se referiam à democratização dos países ex-comunistas, às intervenções nos Bálcãs, ao alargamento da OTAN e à integração da Europa com a incorporação dos países da Europa Oriental à União Européia, principais problemas, pode-se dizer, da política externa do governo Clinton.

Clinton e seu primeiro Secretário de Estado, Warren Christopher, formam a dupla que mais utilizou esse princípio em suas comunicações (mais de $32 \%$ do total dos seus discursos referem-se a esse princípio, o que corresponde a mais de $20 \%$ do total dos discursos dos Secretários que usaram o princípio).

Logo no primeiro ano da administração Clinton, Christopher falaria de forma clara, franca e pragmática sobre o princípio da paz democrática:

Democracies are not just a moral imperative; they are a practical necessity. Democracies do not threaten their neighbours. They do not practice terrorism. They do not spawn refugees. They respond to the needs of their citizens and thereby achieve greater stability and prosperity for all (Warren Christopher, ASEAN Post-ministerial Conference, July, 1993).

Quando o novo cenário do pós-Guerra Fria fica mais bem definido, Clinton declara que a melhor maneira de assegurar paz e segurança duradouras é apoiar a democratização e as reformas pró-mercado no mundo ex-comunista.. Assim, no discurso do State of the Union de 1994 ele diz:

Ultimately, the best strategy to ensure our security and to build a durable peace is to support the advance of democracy elsewhere. Democracies don't attack each other, they make better trading partners and partners in diplomacy. That is why we have supported (...) the democratic reformers in Russia and in the other states of the former Soviet bloc.(...) And this year, because of our work together, enacting NAFTA, keeping our military strong and prepared, supporting democracy abroad, we have reaffirmed America's leadership, America's engagement. And as a result, the American people are more secure than they were before (Bill Clinton, the State of the Union, 1994).

No de 2000, mostra outra vez especial preocupação com a Rússia e a China:

(...) we must continue to encourage our former adversaries, Russia and China, to emerge as stable, prosperous, democratic nations. Both are being held back from reaching their full potential (...) No one can know for sure what direction these 
great countries will choose. But we must do everything in our power to increase the chance they will choose wisely, to be constructive members of the global community. That is why we must support those Russians struggling for a democratic, prosperous future; continue to reduce both our nuclear arsenals; and help Russia safeguard weapons and materials that remain. That is why Congress should support the agreement we negotiated to bring China into the WTO, by passing Permanent Normal Trade Relations as soon as possible this year. Our markets are already open to China. This agreement will open China's markets to us. And it will advance the cause of peace in Asia and promote the cause of change in China (Bill Clinton, the State of the Union, 2000).

Em 1995, Christopher explicita o objetivo maior da política de aumento dos membros da OTAN:

NATO enlargement remains an essential part of our strategy to build a more integrated Europe of democracies at peace. It is essential that our efforts to integrate these states remain open and inclusive (Intervention on the North Atlantic Ministerial Meeting, May, 1995).

No ano seguinte, o Secretário expressa a política externa em relação à Rússia em termos do $2^{\circ}$ princípio:

Far from fearing the result, we should be confident that in the long run, democracy in Russia can only benefit Europe, America and the world. Whatever Russia's future holds in store, our interests will remain the same: to keep our people safe and to consolidate the gains for peace and freedom made possible by the Cold War's end. Our support for the democratic process in Russia and our cooperation on security issues will be critical in the months and years ahead (Remarks to the North Atlantic Council, June 1996).

Madeleine Albright segue na mesma linha, também utilizando o princípio da paz kantiana para justificar intervenções americanas e da OTAN ou outras medidas da política externa americana. Durante sua gestão, Albright ligou democracia à paz, segurança e estabilidade principalmente a duas regiōes: os Bálcãs e a Ucrânia. No que se refere a esta última, a Secretária expressou várias vezes perante vários Comitês da Câmara e do Senado durante os anos de 1998 e 1999 que uma Ucrânia independente, democrática, próspera e estável seria a chave para a construção de uma Europa segura e não dividida. E finalmente, durante sua apresentação ao Senado do Orçamento para os Assuntos Internacionais para o ano fiscal de 2001, Albright deixa claro que:

Aside from Russia, Ukraine is the largest and most influential of the New Independent States. The whole region will be affected by whether it slides backward, 
or continues up the democratic path (Opening Remarks on Fiscal Year 2001, International Affairs Budget before the Senate Foreign Relations Committee, February, 2000).

Quanto aos Bálcãs, seu discurso perante a OTAN, em maio de 2000, é um bom resumo da aplicação do $2^{\circ}$ princípio:

That is why we are striving to build a Europe that is united and strong; where democratic practices are deeply rooted and wars simply do not happen. (...) In both Kosovo and Bosnia, NATO's commitment remains strong. Our goal is to create conditions under which peace will be self-sustained, so that when our troops do depart, they do not have to return. To this end, we must be steadfast in our commitment to democratic principles, economic reform and the rule of law (Statement at the Ministerial Meeting of the North Atlantic Council, May, 2000).

Este princípio, durante o governo Bush, teria sua grande utilidade na justificação da invasão militar do Iraque para combater o terrorismo e implantar a democracia no Oriente Médio e assim levar a paz e a estabilidade à região mais conturbada do planeta. Sabe-se que Powell não se sentia confortável com essa solução de força. Dessa forma, seus poucos discursos que usavam o princípio da paz kantiana, evitavam falar de guerra. Por exemplo:

We are not now talking about a matter of war. We are talking about a matter of peace. We are talking about a matter of hope. We are talking about helping the Iraqi people, and this resolution has that as its singular purpose: to help the Iraqi people to obtain a better life for themselves and their children and to put in place a democratic form of government representing all the people of Iraq that will live in peace with its neighbors and be a responsible nation among the family of nations (Remarks to the Press after Secretary Powell's Meeting with UN Secretary General Kofi Annan, May 2003).

Na verdade, Powell falava de guerra - war on terrorism - mas quase sempre em situações bem específicas: todos os anos perante os diversos Comitês das duas Casas do Congresso, quando defendia o orçamento proposto pelo Presidente para o próximo Ano Fiscal. Suas exposições começavam invariavelmente pela afirmação de que "Our number one priority is to fight and win the global war on terrorism" e a partir daí justificava a ajuda econômica, militar e a "assistência democrática" proposta para os principais aliados nesta guerra, para a construção da democracia em determinadas regióes (Oriente Médio, Colômbia), e o orçamento proposto para determinadas áreas do Executivo. A guerra ao terrorismo, contudo, cuja estratégia principal de combate foi definida pelo governo Bush como sendo a exportação de democracia pelo uso da força, foi quase sempre justificada por Powell a partir do terceiro princípio, como se verá abaixo. 
O exame dos discursos de Bush e Powell neste período permite dizer que coube ao Presidente expor claramente sua nova e dura política externa a qual, quebrando o isolacionismo dos primeiros meses e botando grande ênfase na ação militar preventiva, ainda assim recorria aos mesmos princípios da promoção da democracia identificados neste artigo. É o que procuraremos demonstrar em seguida.

Menos de um mês após os atentados terroristas, em 7 de outubro de 2001, com ampla aprovação mundial e do Conselho de Segurança da ONU, começam as operações militares americanas no Afeganistão. Mas as operações de força não parariam aí. Bush deixara claro no discurso proferido 9 dias após os ataques às torres gêmeas e ao Pentágono que "Our war is with Al Qaida, but it does not end there. It will not end until every terrorist group of global reach has been found, stopped, and defeated" (cf. Address to the Nation on the Terrorists Attacks, Setembro 20, 2001). Dessa forma, durante o ano de 2002, Bush e sua equipe neoconservadora de política externa procuram preparar a população para a guerra do Iraque. Este grupo trata de estabelecer ligaçōes entre o país e a Al Qaeda (cf. Cameron, 2005), enquanto os serviços de inteligência apontam para a existência de armas de destruição de massa. Em discurso de 17 de março de 2003, Bush defende claramente a solução de força contra ditadores assassinos com o objetivo de se assegurar a paz:

The cause of peace requires all free nations to recognize new and undeniable realities. In the 20th century, some chose to appease murderous dictators, whose threats were allowed to grow into genocide and global war. In this century, when evil men plot chemical, biological, and nuclear terror, a policy of appeasement could bring destruction of a kind never before seen on this Earth (Address to the Nation on Iraq, 3/17/2003).

Neste mesmo mês, mesmo sem a autorização do Conselho de Segurança da ONU e a oposição da França, Alemanha, Rússia e China, Bush decide invadir o Iraque. Tony Blair seria seu fiel aliado. Ao longo deste ano, o Presidente faria importantes discursos mostrando o significado da guerra do Iraque para a segurança do mundo como um todo e dos Estados Unidos em particular (este último aspecto será tratado quando examinarmos o terceiro princípio). Mas a segurança viria não pela dominação de um povo que abrigaria terroristas ou a conquista de um território, mas pela crença no princípio da paz democrática. Antes da invasão do Iraque, Bush explicita a relação entre o avanço da democracia, o enfraquecimento do apelo do terrorismo e a busca da paz:

Our commitment to liberty is America's tradition, declared at our founding, affirmed in Franklin Roosevelt's Four Freedoms, asserted in the Truman Doctrine and in Ronald Reagan's challenge to an evil empire. We are committed to freedom in Afghanistan, in Iraq, and in a peaceful Palestine. The advance of freedom is 
the surest strategy to undermine the appeal of terror in the world. Where freedom takes hold, hatred gives way to hope. When freedom takes hold, men and women turn to the peaceful pursuit of a better life (Address to the Nation on Iraq from the U.S.S. Abraham Lincoln, 5/1/2003).

\section{E depois:}

The Middle East will either become a place of progress and peace, or it will be an exporter of violence and terror that takes more lives in America and in other free nations. The triumph of democracy and tolerance in Iraq, in Afghanistan, and beyond would be a grave setback for international terrorism. The terrorists thrive on the support of tyrants and the resentments of oppressed peoples. When tyrants fall and resentment gives way to hope, men and women in every culture reject the ideologies of terror and turn to the pursuits of peace. Everywhere that freedom takes hold, terror will retreat (Address to the Nation on the War on Terror, 9/07/2003).

A partir de 2005, Bush ganha o reforço de Condoleezza Rice. Note-se que Rice é a Secretária que individualmente e em termos absolutos mais usa o princípio da paz kantiana em suas comunicações (ver Tabela IV). Bush e Rice repetiriam inúmeras vezes, didaticamente, perante diversas audiências: (1) sua crença no princípio da paz democrática e (2) que democracia é a única arma eficaz no combate ao terrorismo. Exemplos em 2005:

Our aim is to build and preserve a community of free and independent nations, with governments that answer to their citizens and reflect their own cultures. And because democracies respect their own people and their neighbors, the advance of freedom will lead to peace (George W. Bush, State of the Union, January 2005).

(The Iraqi people) are determined to carry out a political process that will lead to a free and democratic Iraq. And we believe that the region, and indeed the world, will be more secure when that day is realized. It is that reason that the international community today strongly demonstrated its support and friendship and solidarity with the Iraqi people (Condoleezza Rice, Joint Press Availability with European Union Presidency, Foreign Minister and President of the Council, UN Secretary General, Iraqi Foreign Minister, European Union External Relations Commissioner and European Union High Representative after the International Conference on Iraq, June, 2005).

Em 2006, o reforço dessas idéias ficaria, por assim dizer, mais a cargo de Rice. Por exemplo, justificando o orçamento da política externa perante o Congresso:

I want to just note that the President's budget, the ' 07 budget, is in support of a foreign policy that is devoted to the spread of liberty and democracy as the best 
antidote to the ideologies of hatred that feed the kind of terrorism that we have experienced and that many others around the world have experienced as well (Condoleezza Rice, President's Fiscal Year 2007 Budget Request, March 2006).

Rice se refere ao Afeganistão dentro da mesma concepção. É interessante notar no texto selecionado que se segue, a referência da Secretária à transformação do papel da OTAN:

We are transforming NATO into an alliance that its founders might not have recognized but would certainly have celebrated: an alliance of free nations joined in common effort with other great democracies from across the globe, to support the growth of peace and freedom throughout the world. Now we must fulfill our commitment to success in Afghanistan - for in so doing, we will help a new democracy take root in the heart of a troubled region, and we will make a lasting contribution to the security of our world Condoleezza Rice, Fulfilling the Commitment to Success in Afghanistan, Press Availability with UN Secretary General Ban Kimoon, January, 2007).

Em resumo, ao evocar o princípio da paz democrática como justificativa para suas açôes de política externa, inclusive militares, a única potência dopós-Guerra Fria assegurava ao mundo estar dando sua "duradoura contribuição para a paz e segurança mundiais.

\section{A Missão Americana: levar liberdade e democracia a toda a humanidade}

Pode-se dizer que os princípios um e dois - a universalidade dos valores democráticos e a paz democrática - combinam-se para constituir o que aqui chamamos a "missão americana". Os Presidentes e seus Secretários falam de destino manifesto, de Deus, do mal, fardo, sacrifício, chamado especial, missão. As palavras transmitem sentimentos nobres, quase religiosos. Algumas vezes assumem a postura do "povo escolhido", outras vezes mostram indiscutível arrogância. Esse sentido de missão apareceria em momentos importantes da política externa no pós-Guerra Fria.

Assim, quando no início dos anos 1990 a União Soviética e o mundo comunista de uma maneira geral se esfacelam, o Presidente George H. W. Bush vislumbra uma nova ordem internacional, um novo mundo, onde "America stands at the Center of a widening circle of freedom - today, tomorrow, and into the next century" (State of the Union, 1990). No ano seguinte, aparecerá claramente o sentido de missão e de "povo escolhido":

(...) today, in a rapidly changing world, American leadership is indispensable. Americans know that leadership brings burdens and sacrifices. But we also know 
why the hopes of humanity turn to us. We are Americans; we have a unique responsibility to do the hard work of freedom. And when we do, freedom works (speech of the State of the Union, 1991).

Durante a administração Clinton ficou mais claro o papel exigido da única superpotência: a de peace-broker na Europa e interventor humanitário na África. ${ }^{5}$ A missão americana de liderar a luta pela liberdade e pela paz através do mundo é, então, fortemente enfatizada.

O exame da Tabela VI e da Figura VI mostra que Madeleine Albright é a Secretária que mais se refere à missão americana de promover a liberdade no mundo, o que ocorre em mais de $20 \%$ dos seus discursos analisados, correspondendo a mais de $50 \%$ do total dos discursos dos Secretários que se referem a essa missão. Cita-se um exemplo típico desses discursos:

I begin with the observation that we all know America's purpose. It is freedom. We Americans are dedicated to the rights of all people. We promote government with the consent of the governed. We believe in law. We cherish peace. We seek prosperity. (...) We Americans draw immense strength from the fact that we know who we are and what we believe. We have a purpose. And like the farmer's faith that seeds and rain will cause crops to grow; it is our faith that if we are true to our principles, we will succeed. Let us, then, do honor to that faith. In this final year of this turbulent century, let us assume, not with complaint, but welcome, the leader's role established by our forebears. And by living up to the heritage of our past, let us fulfill the promise of our future - and enter the new century free and united, prosperous and at peace. To that mission, I pledge my own best efforts, and respectfully solicit both your wise counsel and support (Madeleine Albright, Testimony on Fiscal Year-2000 Budget, February 1999).

Os discursos de Albright enfatizam que a força da liderança americana no mundo pós-Guerra Fria não vem apenas do seu poder econômico ou militar, mas deriva sobretudo do poder dos seus ideais, onde são fundamentais o compromisso com a democracia, os direitos humanos e o estado de direito (ver, por exemplo, Opening Remarks before the Senate Appropriations Committee, Subcommittee on Foreign Operations. March and June 1998).

Vale destacar, também, na entrevista à NBC-TV, em 1998, sobre a possibilidade de ataques aéreos contra Saddam Hussein, um trecho onde a Secretária, assumindo um tom inequivocamente arrogante, deixa mais claro do que nunca que a América tem uma missão perante o mundo que exige sacrifícios e à qual seu povo não se nega porque é o "povo escolhido":

5 O papel dos Estados Unidos na nova ordem internacional, especialmente frente às alternativas de xerife do mundo, líder responsável ou posição isolacionista, é discutido em Castro Santos, 2010-b. 
Let me say that we are doing everything possible so that American men and women in uniform do not have to go out there again (...) But if we have to use force, it is because we are America; we are the indispensable nation. We stand tall and we see further than other countries into the future, and we see the danger here to all of us. I know that the American men and women in uniform are always prepared to sacrifice for freedom, democracy and the American way of life (Madeleine Albright, Interview to NBC-TV, 1998).

No período Bush como demonstra a análise da Tabela VI e Figura VI, o "chamado da história" ao povo americano para cumprir sua missão de defender e levar a liberdade a todos os povos do mundo é significativamente mais utilizado na primeira administração: tanto pelo Presidente quanto por seu Secretário. Este é um fato que faz todo o sentido: em momento de grande ameaça ao país e tendo a resposta do governo vindo em forma de uma doutrina de política externa de grande agressividade, que inclusive previa a guerra preventiva, era fundamental reforçar a missão de levar a democracia e a liberdade aos outros povos, mesmo que pelo uso da força. Invadir o Iraque, como medida preventiva, alegando a existência de armas de destruição em massa (que nunca apareceram) e de conspirações da Al Qaeda em conluio com Saddam Hussein (ligações que nunca se provaram reais), tinha que parecer aos olhos do povo americano como a coisa certa a fazer, e mais, que só eles podiam fazer. Não se tratava aqui apenas da segurança dos Estados Unidos, a retórica da missão americana reforçava a importância daquela guerra para a humanidade, era quase uma "guerra santa":

This is not, however, just America's fight. And what is at stake is not just America's freedom. This is the world's fight. This is civilization's fight. This is the fight of all who believe in progress and pluralism, tolerance and freedom (Georege W. Bush, September 20, 2001).

Em 2002, quando se preparava a Guerra do Iraque, vários discursos de Bush enfatizavam o "chamado da história" e a responsabilidade de velar, por assim dizer, pela liberdade dos povos da terra. Seguem-se alguns trechos:

History has called America and our allies to action, and it is both our responsibility and our privilege to fight freedom's fight. (...) And we have a great opportunity during this time of war to lead the world toward the values that will bring lasting peace (George W. Bush, State of the Union, 2002).

History has called our Nation into action. History has placed a great challenge before us: Will America, with our unique position and power, blink in the face of terror, or will we lead to a freer, more civilized world? There's only one answer: This great country will lead the world to safety, security, peace, and freedom 
(George W. Bush, Address to the Nation on the Proposed Department of Homeland Security, June 2002).

Tomorrow is September the 12th. A milestone is passed, and a mission goes on. Be confident. Our country is strong, and our cause is even larger than our country. Ours is the cause of human dignity, freedom guided by conscience and guarded by peace. This ideal of America is the hope of all mankind (George W. Bush, Address to the Nation on the Anniversary of the Terrorist Attacks of September 11, from Ellis Island, New York, Septemper 11, 2002).

Alguns meses após a invasão do Iraque, o mesmo discurso continua:

We accept the duties of our generation. We are active and resolute in our own defense. We are serving in freedom's cause, and that is the cause of all mankind (George W. Bush, Address to the Nation on the War on Terror, September 2003).

Na mesma ocasião, Colin Powell, referindo-se à missão de levar democracia ao Iraque e ao Afeganistão, expressa-se de forma indubitavelmente arrogante:

We fight terrorism because we must. We seek a better world because we can, because it is our desire, it is our destiny to do so. That is why we devote ourselves to democracy, development, global public health, human rights - as well as to the structure of global peace that enables us to pursue our vision for a better world (Colin Powell, Remarks at the Elliot School of International Affairs, George Washington University, Washington DC, September, 2003).

Um ano depois o tom de missão continua, uma missão que cumpre as intenções de Deus:

America will continue to live out its destiny of helping people around the world achieve their own form of freedom, their own form of democracy so that their people, too, can live as God intended them to live: free (...) (Colin Powell, Remarks at the Southern Center for International Studies, Atlanta, October, 1, 2004).

Bush relembra a "missão da América" no discurso do State of the Union de 2004 e no discurso de posse do $2^{\circ}$ mandato, em 2005, de forma muito clara:

And above all, we will finish the historic work of democracy in Afghanistan and Iraq so those nations can light the way for others and help transform a troubled part of the world. America is a nation with a mission, and that mission comes from our most basic beliefs. We have no desire to dominate, no ambitions of empire. Our aim is a democratic peace, a peace founded upon the dignity and rights of every man and woman. America acts in this cause with friends and allies at our side, yet we 
understand our special calling: This great Republic will lead the cause of freedom (George W. Bush, State of the Union, 2004).

Across the generations, we have proclaimed the imperative of self-government, because no one is fit to be a master and no one deserves to be a slave. Advancing these ideals is the mission that created our Nation. It is the honorable achievement of our fathers. Now, it is the urgent requirement of our Nation's security and the calling of our time (George W. Bush, Inaugural Address, 2005).

A retórica dos princípios 1 e 2 e da missão americana, analisadas até aqui, é altruísta, dirigida para o bem dos outros povos do mundo e para a paz mundial. São pilares da política externa americana sem dúvida moralmente justificáveis. Mas e a segurança da única superpotência do mundo, dramaticamente abalada com os ataques de 11 de setembro? A ajuda aos países ex-comunistas não poria em risco a segurança americana? E os interesses americanos? Como são levados em conta na doutrina da política externa do período do pós-Guerra Fria, onde democracia deve agora ser peça fundamental? É aqui que entra o $3^{\circ}$ princípio identificado na pesquisa e que justamente vai ligar segurança e os interesses americanos aos pilares, por assim dizer, mais ideológicos da política externa sob exame.

\section{Princípio 3: a exportação de democracia torna o mundo mais seguro e mais próspero para os Estados Unidos:}

Do ponto de vista acadêmico, há na área mais propriamente das Relações Internacionais uma literatura que não vê contradição entre a difusão da democracia, a segurança e os interesses dos Estados Unidos (cf. Owen, 2006). Na literatura de democratização essa conexão também é claramente reconhecida: "A more democratic world would be a safer, saner and more prosperous world for the United States" (Diamond: 1992, 30).

Esses vínculos entre a segurança, os interesses americanos e a promoção da democracia estabelecidos pelo aqui chamado $3^{\circ}$ princípio são parte fundamental da doutrina da política externa americana no pós-Guerra Fria. De fato, este pilar da doutrina assegura que os princípios da democracia liberal não descuidam dos interesses nacionais vitais dos Estados Unidos, muito pelo contrário, é sua garantia. Ele apareceria em momentos importantes da política externa, conforme demonstram os discursos analisados abaixo.

Os vínculos explicitados pelo $3^{\circ}$ princípio explicam, por exemplo, porque intervir no Oriente Médio recebe alta prioridade enquanto intervenções humanitárias na África ou mesmo nos Bálcãs são mais relutantes. A referência de Bush senior à Guerra do Golfo em seu discurso do State of Union de 1991 ilustra bem esse ponto. Usando ainda uma clara linguagem da Guerra Fria, diz o Presidente: 
Most Americans know instinctively why we are in the Gulf. They know we had to stop Saddam now, not later. (...) They know we must make sure that control of the world's oil resources does not fall into his hands, only to finance aggression. They know that we know to build a new, enduring peace, based not on arms race and confrontation but on shared principles and the rule of law (George W. H. Bush, Speech of the State of the Union, 1991).

Para Clinton o recurso a esse princípio foi de grande importância para justificar sua política externa. Como se viu, sua administração enfrentou o enorme desafio de definir a política externa americana em relação aos países excomunistas. Coerentemente com os pilares da política externa do pós-Guerra Fria aqui identificados, ele enfatizou a importância de apoiar estes países na construção de regimes políticos democráticos e de mercados livres. Prosseguindo com coerência ele foi adiante e incentivou o alargamento da OTAN, incorporando muitas dessas novas democracias. Entretanto, havia preocupação entre o povo americano e dentro do Congresso se esta política não solaparia a segurança dos Estados Unidos. Clinton, além de assegurar que as Forças Armadas não sofreriam cortes de orçamento e que sua prontidão e capacidade técnica seriam mantidas em seu melhor nível, afirmou claramente a importância de difundir a democracia para a segurança e prosperidade americana:

We must also remember as these nations chart their own futures (...) how much more secure and more prosperous our own people will be if democratic and market reforms succeed all across the former Communist bloc (Bill Clinton, Speech of the State of the Union, 1994).

No que diz respeito à Europa, Clinton usa os mesmos argumentos ao declarar, no seu discurso do State of the Union de 1997, que “(...) our first task is to help to build for the very first time, an undivided, democratic Europe. When Europe is stable, prosperous, and at peace, America is more secure (...)." Repeteos incansavelmente a cada intervenção americana para restaurar a democracia combinada ao caráter humanitário. É assim no que se refere ao Haiti (cf. Address to the Nation on Haiti, setembro 1994), à Bósnia-Herzegovina (Address to the Nation on Implementation of the Peace Agreement in Bósnia-Herzegovina, novembro 1995), aos ataques aéreos contra a Sérvia (Address to the Nation on Airstrikes against Serbian targets in the Federal Republic of Yugoslavia -Serbia and Montenegro, março 1999), ao Kosovo (Address to the Nation on the Military Technical Agreement on Kosovo, junho 1999). Note-se que na grande maioria das vezes Clinton liga a promoção de democracia tanto à segurança quanto aos interesses econômicos americanos.

Warren Christopher, referindo-se ao mesmo tema, reafirmou de maneira, por assim dizer, mais crua, o $3^{\circ}$ princípio em um Encontro da OTAN: 
(...) the states of Central and Eastern Europe, and the former Soviet Union, need our help. These countries are trying to develop into free market democracies. Assisting them is not charity: it is essential to our own common security (Warren Christopher, Encontro Especial da OTA, Bruxelas, fevereiro, 1993).

Um mês antes o Secretário deixara bem claro que a promoção da democracia e o apoio aos direitos humanos fora das fronteiras americanas eram sustentáculos estratégicos centrais da segurança dos Estados Unidos: "Promoting democracy does not imply a crusade to remake the world in our image. Rather, support for democracy and human rights abroad can and should be a central strategic tenet in improving our own security" (Statement at Senate Confirmation Hearing, janeiro, 1993).

Dois meses depois ele repetiria a mesma idéia perante o Conselho de Relações Internacionais do Clube de Executivos de Chicago (março, 1993): "By helping promote democracy, we do more than honour our deepest values. We are also making a strategic investment in our nation's security. History has shown that a world of more democracies is a safer world."

A administração Bush é marcada pelos ataques terroristas em solo americano, o que o obriga a sair de uma posição inicial na política externa de grande isolacionismo para uma posição de defesa agressiva. Como visto, a estratégia principal de defesa definia-se pela exportação de democracia pelo uso da força, já que democracia era o antídoto para o terrorismo.

Assim como o $2^{\circ}$ princípio, o $3^{\circ}$ seria de fundamental importância para justificar a Doutrina Bush. A passagem a seguir, extraída do discurso de Bush do State of the Union de 2004 é particularmente clara:

As long as the Middle East remains a place of tyranny and despair and anger, it will continue to produce men and movements that threaten the safety of America and our friends (George W. Bush, State of the Union, janeiro, 2004).

Esta idéia é ainda melhor expressa no discurso do State of the Union de 2006:

On September 11, 2001, we found that problems originating in a failed and oppressive state 7,000 miles away could bring murder and destruction to our country. Dictatorships shelter terrorists, feed resentment and radicalism, and seek weapons of mass destruction. Democracies replace resentment with hope, respect the rights of their citizens and their neighbors, and join the fight against terror. Every step toward freedom in the world makes our country safer, and so we will act boldly in freedom's cause (George W. Bush, State of the Union, janeiro 2006).

E seria repetida nos discursos do State of the Union de 2007 e 2008, no discurso inaugural de 2005 , em vários discursos dirigidos à nação sobre a guerra 
ao terrorismo em geral, discursos específicos sobre a guerra no Afeganistão e especialmente no Iraque, mesmo após vários anos de invasão a esses países, com situações ainda indefinidas e instáveis e perdas crescentes de vidas afegãs, iraquianas e americanas (cf. Address to the Nation on Iraq from the U.S.S. Abraham Lincoln, maio 2003; Address to the Nation on the War on Terror, setembro 2003; Address to the Nation on the War on Terror from Fort Bragg, North Carolina, junho, 2005; Address to the Nation on the War on Terror in Iraq, janeiro, 2007).

Condoleezza Rice, com maior proximidade ideológica de Bush do que Powell, como já referido, reforçou significativamente, por assim dizer, a cruzada do Presidente contra o terrorismo pela promoção agressiva da democracia. No mesmo mês em que tomou posse (janeiro de 2005), Rice enfatizou a democracia como instrumento para defender os interesses e a segurança dos Estados Unidos em pelo menos três ocasióes. Diante do Comitê do Senado de Relações Externas a Secretária disse que: "More than ever, America's diplomats will need to be active in spreading democracy, fighting terror, reducing poverty, and doing our part to protect the American homeland.” Em uma entrevista à CNN Rice assim se expressou: "(...) our military people and our diplomats are taking tremendous risks, (...) they are putting their lives on the line for the exercise of democracy in support of our security and freedom." No final do mês ela simplesmente afirma que os americanos devem mudar o Oriente Médio:

We face a world in which we recognize after September $11^{\text {th }}$ that we have to have change in the Middle East, change based on democratic values, change based on the spread of liberty, because without the dignity and the hope that liberty and freedom bring, we're going to see nothing but the kind of hopelessness that terrorism brings. And we now understand that we have to have a different kind of Middle East. It's time, again, when America' values and America's interests are completely linked (Condoleezza Rice, Remarks at Town Hall Meeting, janeiro, 2005).

Ao longo dos anos do seu mandato, Rice lançaria mão do $3^{\circ}$ princípio em $20 \%$ do total dos seus discursos analisados para justificar a Doutrina Bush que orientava a política externa do governo a que servia, em igual proporção em que o faria do $2^{\circ}$ princípio, como visto acima. Assim, no $2^{\circ}$ mandato do governo Bush a importância da democracia na agenda de defesa americana crescia significativamente e entrelaçava-se com a política externa.

De uma maneira geral, de acordo com o $3^{\circ}$ princípio, o mundo democrático não é apenas mais seguro para os Estados Unidos, mas é também um mundo que serve aos seus interesses. Esses interesses envolvem não apenas segurança, mas também interesses econômicos. E, acrescente-se, certamente incluem também interesses políticos e geopolíticos.

A análise dos discursos mostrou ainda que o terceiro princípio freqüentemente vem associado ao segundo nos discursos dos Presidentes e seus Secretários de 
Estado: importa aos tomadores de decisão convencer a sociedade e o Congresso que, além da paz e da segurança mundial a democracia traz também segurança e prosperidade para os Estados Unidos (cf. os fragmentos de discursos ilustrativos do $2^{\circ}$ e $3^{\circ}$ princípios acima).

O terceiro princípio é crucial na composição da doutrina de política externa americana no período do pós-Guerra Fria: ele liga a dimensão normativa e ideológica da doutrina a sua dimensão pragmática, possibilitando a sua implementação política.

\section{Conclusões: mais do mesmo?}

Motivou este trabalho a busca dos pilares da doutrina da política externa americana no período do pós-Guerra Fria que justificam a exportação de democracia pelo uso da força, investigando-se o lugar que aí ocupam democracia e segurança.

Podia-se imaginar que com o esfacelamento do mundo comunista e sem grandes ameaças aparentes, democracia passaria a ocupar lugar proeminente na política externa americana, agora "sem as ambigüidades da guerra fria", quando os Estados Unidos apoiavam ditaduras pró-americanas (Farer, 1996). Na verdade, isso se aplicaria, sobretudo, ao governo Clinton, cujas ações militares estiveram na categoria de intervenção humanitária (Somália) e na modalidade de peacebroker (Bálcãs). Dos governos Bush pai e Bush filho, que comandaram guerras no Oriente Médio, seria de se esperar maior preocupação com segurança.

Os resultados da análise quantitativa dos 415 discursos dos Presidentes e Secretários de Estado contrariou essas expectativas. De fato, se a ocorrência da palavra segurança e afins em comparação com democracia e correlatas nos discursos examinados segue o esperado na administração de Bush pai,isto é, cresce substancialmente nos anos da Guerra do Golfo, na administração Clinton a predominância de segurança, sobretudo à conta dos Secretários de Estado, não parece condizer, à primeira vista, com as principais questóes de política externa do governo: apoio aos países ex-comunistas, alargamento da OTAN, integração da Europa, peace-broker nos Bálcãs, intervenção humanitária na Somália.

Mais surpreendente é o pico de utilização da palavra democracia e derivadas nos discursos de George W. Bush e sua Secretária Condoleezza Rice, quando, poucos meses após o início do seu governo, uma grande ameaça aos Estados Unidos aparece na forma dos ataques de 11 de setembro às Torres Gêmeas e ao Pentágono.De fato, a draconiana resposta dos neocons na forma da chamada Doutrina Bush, baseada em guerra preventiva e ação unilateral, faria supor uma forte predominância de segurança.

Ao definir empiricamente os pilares da política externa americana do pós-Guerra Fria, a análise qualitativa dos discursos possibilitou entender esses resultados. 
Identificou-se, assim, três princípios e uma missão americana, todos presentes nos discursos de todos os Presidentes e Secretários de Estado: além dos valores e princípios da democracia serem considerados universais $\left(1^{\circ}\right)$, sua exportação é vista não só como conducente à paz mundial, já que democracias não lutam entre si $\left(2^{\circ}\right)$, como também é garantia da segurança e dos interesses dos Estados Unidos $\left(3^{\circ}\right)$. A missão a que se atribuem os americanos, que permeia e reforça os princípios, é a de difundir e levar liberdade a todos os povos do mundo.

Os princípios $\underline{2}$ e $\underline{3}$ trazem uma ligação inequívoca entre democracia e segurança, tanto ao nível global como no que se refere especificamente aos Estados Unidos. Esses dois princípios são, inclusive, usados com frequiência de forma complementar nos discursos analisados.

Para Clinton e principalmente seu primeiro Secretário, os dois princípios foram muito importantes para justificar perante o Congresso e o povo americano de uma maneira geral que sua política em relação aos países ex-comunistas (apoiálos na democratização, na construção do mercado, na diminuição simultânea do arsenal nuclear), de alargamento da OTAN e integração da Europa não só traria paz como não poria em risco os Estados Unidos. $\mathrm{O}$ uso freqüente desses principios explicaria a grande preocupação com segurança na administração Clinton, o que à primeira vista não pareceria razoável.

$\mathrm{O} 2^{\circ}$ e o $3^{\circ}$ princípios foram também largamente usados no governo Bush, principalmente pelo Presidente e sua segunda Secretária, Condoleezza Rice. A ênfase é mais do que nunca posta em democracia, na medida em que sua exportação é definida como o antídoto ao terrorismo, a única arma capaz de combatê-lo e, portanto, capaz de trazer segurança ao mundo e "em casa." Rice e Bush discursam incansavelmente, justificando as invasões no Oriente Médio em nome da democracia. A Bush, sobretudo, caberia também reforçar junto ao povo americano sua missão de levar a liberdade aos povos submetidos. Esses discursos seriam particularmente freqüentes em 2002, quando ele, por assim dizer, preparava o povo americano para a invasão do Iraque, falando na ocasião do "chamado da história para a América lutar a luta da liberdade, a luta das civilizaçôes". Ao mesmo tempo, o Presidente e os dois Secretários contestavam, em vários discursos, a tese de Huntington, afirmando que não havia incompatibilidade entre democracia e o islamismo. Esta grande proeminência da democracia na doutrina da política externa de Bush explica a utilização desse vocábulo e seus derivados significativamente maior do que segurança e palavras afins em seus discursos e nos de Rice.

A partir desses resultados pode-se formular a seguinte hipótese: quanto mais agressiva for a doutrina de política externa maior será o reforço dos princípios da doutrina de exportação de democracia identificada neste trabalho no discurso dos policy-makers. Isto é, mais trabalho, por assim dizer, terão os tomadores de decisão para mostrar que sua doutrina não é incompatível com os princípios da democracia liberal e da exportação de democracia. 
Vale ainda algumas observações sobre as conexões dos pilares da política externa americana aqui identificados. Observe-se, em primeiro lugar, que o primeiro princípio e a missão americana reforçam-se mutuamente. Ou seja: todos os povos do mundo desejam se tornar democráticos e é missão do "povo escolhido" levar-lhes a liberdade a muito desejada e merecida. Albright se expressa recorrentemente dessa maneira. Powell fala do destino de ajudar os povos a viver livres, como é a intenção de Deus. O $2^{\circ}$ princípio, como os anteriores, é também altruísta: os três pilares voltam-se para o bem dos outros povos do mundo e para a paz global. É o $3^{\circ}$ princípio que se distingue dos demais e por isso mesmo é fundamental na composição da doutrina da política externa aqui examinada. De fato, ao ligar a dimensão normativa da doutrina à sua dimensão pragmática, seus formuladores acrescentam sua peça crucial e final. Assim, mantendo a visão fukuyamaniana da democracia, pelo $3^{\circ}$ princípio vinculam-na à segurança e aos interesses americanos. A exportação da democracia pelo uso da força fica justificada se alguma grande ameaça é detectada. Mas as invasões militares que se seguem não são movimentações de um Império do Mal, pois o primeiro princípio garante que o povo do país invadido deseja a democracia e se ameaça houve é porque o governo desse país está dominado por uma elite autoritária ou por um grande ditador do mal, à la Saddam Hussein. Os americanos, então, esperam ser recebidos como libertadores e rapidamente ajudar a instalar a democracia, garantindo, assim, pelo $2^{\circ}$ princípio, a paz na região e, em conseqüência, estendo-se pelo mundo.

Em conclusão, fica a sugestão de que os princípios liberais tradicionais onde se baseia a política externa americana estão sempre presentes e são sempre os mesmos, quaisquer que sejam as doutrinas que a embase, desde os founding fathers. Assim, para tratar a questão do desenvolvimento político dos países subdesenvolvidos, Packenham (1973) identifica e analisa três doutrinas no período da guerra fria: a de segurança, a econômica e a democrática. No pós-Guerra Fria, como se viu, predomina a doutrina comprometida com a democracia. A questão são conflitos étnicos nos Bálcãs? A paz democrática é a melhor soluçãa. A União Soviética desmoronou? Vamos ajudar a Rússia a se tornar democrática. Terrorismo? A solução mais eficaz é a exportação de democracia, mesmo que pela força das armas. Além da democracia garantir segurança e prosperidade para os Estados Unidos, esta leva a liberdade há muito desejada pelos povos submetidos. A visão americana é, por assim, dizer, solidamente homogênea, como a do médico homeopata unicista. Descoberto o remédio essencial para o bem estar do paciente trata-se de administrálo, sempre o mesmo, em doses variáveis conforme a gravidade da doença. O país vai mal? Está sob grande ameaça? Há que se reforçar o mesmo remédio, isto é, os mesmos princípios democráticos que tornam palatáveis as soluçôes mais agressivas, aqueles mesmos princípios que dão o forte sentido de nação a esta grande nação. Não foi o que Bush fez?

Se esta conclusão está certa, não há motivo para se pensar que Obama fará alguma revisão nos três princípios da doutrina de promoção de democracia 
identificados aqui ou abrirá mão da missão americana. Ele se afastará da Doutrina Bush, conforme promessas de campanha, e provavelmente enfatizará menos os três princípios na medida em que provavelmente haverá menos intervenções. Mas se alguma grande ameaça aos Estados Unidos ocorrer provavelmente ele não hesitará em tomar medidas de força, unilateralmente se preciso for, e, como seus predecessores, procurará reforçar os princípios da doutrina de exportação de democracia. Mais do mesmo.

\section{Tabela I}

Ocorrência das palavras "democracia" e "segurança" nos discursos dos Presidentes americanos, 1989-2008*

\begin{tabular}{|c|c|c|c|c|c|}
\hline Presidente & Ano & Democracia** & $\begin{array}{l}\text { Ocorrência por } \\
1.000 \text { palavras }\end{array}$ & Segurança $a^{* * *}$ & $\begin{array}{l}\text { Ocorrência por } \\
1.000 \text { palavras }\end{array}$ \\
\hline $\begin{array}{c}\text { George } \\
\text { H. W. Bush }\end{array}$ & $\begin{array}{l}1989 \\
1990 \\
1991 \\
1992\end{array}$ & $\begin{array}{r}93 \\
34 \\
77 \\
4\end{array}$ & $\begin{array}{l}5,2 \\
3,5 \\
4,0 \\
0,4\end{array}$ & $\begin{array}{r}63 \\
34 \\
112 \\
23\end{array}$ & $\begin{array}{l}3,5 \\
3,5 \\
5,8 \\
2,5\end{array}$ \\
\hline Bill Clinton I & $\begin{array}{l}1993 \\
1994 \\
1995 \\
1996\end{array}$ & $\begin{array}{r}56 \\
67 \\
52 \\
5\end{array}$ & $\begin{array}{l}1,9 \\
5,0 \\
4,0 \\
0,8\end{array}$ & $\begin{array}{l}44 \\
55 \\
75 \\
17\end{array}$ & $\begin{array}{l}1,5 \\
4,1 \\
5,8 \\
2,7\end{array}$ \\
\hline Bill Clinton II & $\begin{array}{l}1997 \\
1998 \\
1999 \\
2000\end{array}$ & $\begin{array}{l}36 \\
20 \\
37 \\
11\end{array}$ & $\begin{array}{l}4,0 \\
1,7 \\
3,3 \\
1,5\end{array}$ & $\begin{array}{l}22 \\
51 \\
60 \\
24\end{array}$ & $\begin{array}{l}2,5 \\
4,3 \\
5,4 \\
3,2\end{array}$ \\
\hline $\begin{array}{l}\text { George } \\
\text { W. Bush I }\end{array}$ & $\begin{array}{l}2001 \\
2002 \\
2003 \\
2004\end{array}$ & $\begin{array}{l}96 \\
67 \\
79 \\
14\end{array}$ & $\begin{array}{l}4,1 \\
4,5 \\
6,2 \\
2,7\end{array}$ & $\begin{array}{r}75 \\
107 \\
69 \\
16\end{array}$ & $\begin{array}{l}3,2 \\
7,2 \\
5,4 \\
3,1\end{array}$ \\
\hline $\begin{array}{c}\text { George } \\
\text { W. Bush II }\end{array}$ & $\begin{array}{l}2005 \\
2006 \\
2007 \\
2008\end{array}$ & $\begin{array}{r}246 \\
63 \\
46 \\
25\end{array}$ & $\begin{array}{r}14,1 \\
6,0 \\
4,2 \\
4,3\end{array}$ & $\begin{array}{r}120 \\
50 \\
70 \\
24\end{array}$ & $\begin{array}{l}6,9 \\
4,8 \\
6,3 \\
4,1\end{array}$ \\
\hline \multicolumn{2}{|c|}{ Total } & 1128 & 4,4 & 1111 & 4,3 \\
\hline
\end{tabular}

* Foram analisados os discursos proferidos entre 20 de janeiro de 1989 (início do governo de George H. W. Bush) e 20 de janeiro de 2009 (término do governo de George W. Bush).

** Inclui as palavras "freedom" e "liberty", consideradas intercambiáveis à palavra "democracy" no contexto da pesquisa. Também estão inclusos os adjetivos (democratic, free) e advérbios (democratically, freely) relacionados. Quando as palavras selecionadas assumiram significados diferentes do interesse desta pesquisa, elas não foram consideradas (ex.: Democratic party, Democratic Republic of Congo, free trade, free enterprise system).

*** Inclui as palavras "safety” " "peace”, consideradas intercambiáveis à palavra "security” no contexto da pesquisa. Também estão inclusos os adjetivos (secure, safe, peaceful) e advérbios (safely, securely, peacefuly) relacionados. Quando as palavras selecionadas assumiram significados diferentes do interesse desta pesquisa, elas não foram consideradas (ex.: safe haven, safeguard, safety zone, social security, peace of mind, peacekeeping, Peace Corps). Fonte: The American Presidency Project, University of California, Santa Barbara. Disponível em: <http:// www.presidency.ucsb.edu>. 


\section{Tabela II}

Ocorrência das palavras "democracia" e "segurança" nos discursos dos Secretários de Estado americanos, 1993-2008*

\begin{tabular}{|c|c|c|c|c|c|}
\hline $\begin{array}{l}\text { Secretário } \\
\text { de Estado }\end{array}$ & Ano & Democracia** & $\begin{array}{l}\text { Ocorrência por } \\
1000 \text { palavras }\end{array}$ & Segurança*** & $\begin{array}{l}\text { Ocorrência por } \\
1000 \text { palavras }\end{array}$ \\
\hline $\begin{array}{c}\text { Warren } \\
\text { Christopher }\end{array}$ & $\begin{array}{l}1993 \\
1994 \\
1995 \\
1996\end{array}$ & $\begin{array}{r}113 \\
62 \\
167 \\
110\end{array}$ & $\begin{array}{l}5,2 \\
5,6 \\
3,3 \\
3,6\end{array}$ & $\begin{array}{l}147 \\
111 \\
290 \\
145\end{array}$ & $\begin{array}{l}6,8 \\
9,9 \\
5,7 \\
4,8\end{array}$ \\
\hline $\begin{array}{l}\text { Madeleine } \\
\text { Albright }\end{array}$ & $\begin{array}{l}1997 \\
1998 \\
1999 \\
2000\end{array}$ & $\begin{array}{l}254 \\
365 \\
215 \\
159\end{array}$ & $\begin{array}{l}4,5 \\
4,8 \\
4,2 \\
4,5\end{array}$ & $\begin{array}{l}203 \\
460 \\
228 \\
192\end{array}$ & $\begin{array}{l}3,6 \\
6,0 \\
4,5 \\
5,4\end{array}$ \\
\hline $\begin{array}{l}\text { Collin } \\
\text { Powell }\end{array}$ & $\begin{array}{l}2001 \\
2002 \\
2003 \\
2004\end{array}$ & $\begin{array}{r}59 \\
67 \\
112 \\
170\end{array}$ & $\begin{array}{l}1,4 \\
1,1 \\
1,4 \\
2,5\end{array}$ & $\begin{array}{r}94 \\
174 \\
233 \\
217\end{array}$ & $\begin{array}{l}2,2 \\
2,9 \\
2,9 \\
3,2\end{array}$ \\
\hline $\begin{array}{l}\text { Condoleezza } \\
\text { Rice }\end{array}$ & $\begin{array}{l}2005 \\
2006 \\
2007 \\
2008\end{array}$ & $\begin{array}{r}192 \\
107 \\
78 \\
373\end{array}$ & $\begin{array}{l}5,9 \\
5,3 \\
3,1 \\
7,6\end{array}$ & $\begin{array}{r}135 \\
77 \\
96 \\
299\end{array}$ & $\begin{array}{l}4,1 \\
3,8 \\
3,8 \\
6,1\end{array}$ \\
\hline Total & & 2603 & 3,7 & 3101 & 4,4 \\
\hline
\end{tabular}

* Foram analisados os discursos proferidos entre 20 de janeiro de 1993 (início do governo de William J. Clinton) e 20 de janeiro de 2009 (término do governo de George W. Bush).

** Inclui as palavras "freedom" e "liberty", consideradas intercambiáveis à palavra "democracy" no contexto da pesquisa. Também estão inclusos os adjetivos (democratic, free) e advérbios (democratically, freely) relacionados. Quando as palavras selecionadas assumiram significados diferentes do interesse desta pesquisa, elas não foram consideradas (ex.: Democratic party, Democratic Republic of Congo, free trade, free enterprise system).

*** Inclui as palavras "safety" e "peace", consideradas intercambiáveis à palavra "security" no contexto da pesquisa. Também estão inclusos os adjetivos (secure, safe, peaceful) e advérbios (safely, securely, peacefuly) relacionados. Quando as palavras selecionadas assumiram significados diferentes do interesse desta pesquisa, elas não foram consideradas (ex.: safe haven, safeguard, safety zone, social security, peace of mind, peacekeeping, Peace Corps).

Fonte: Sítio do Departamento de Estado dos Estados Unidos da América: <www.state.gov>. 


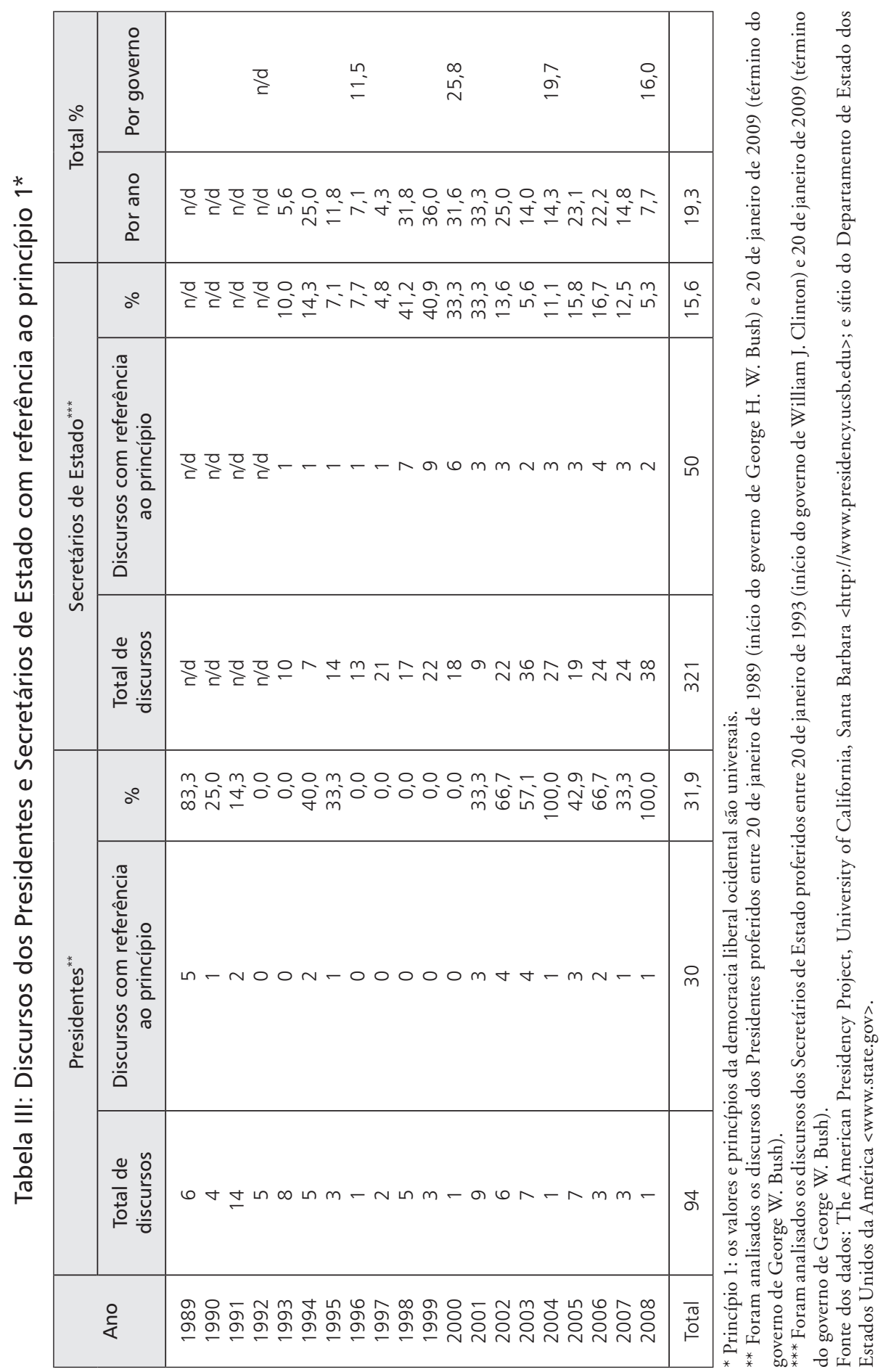




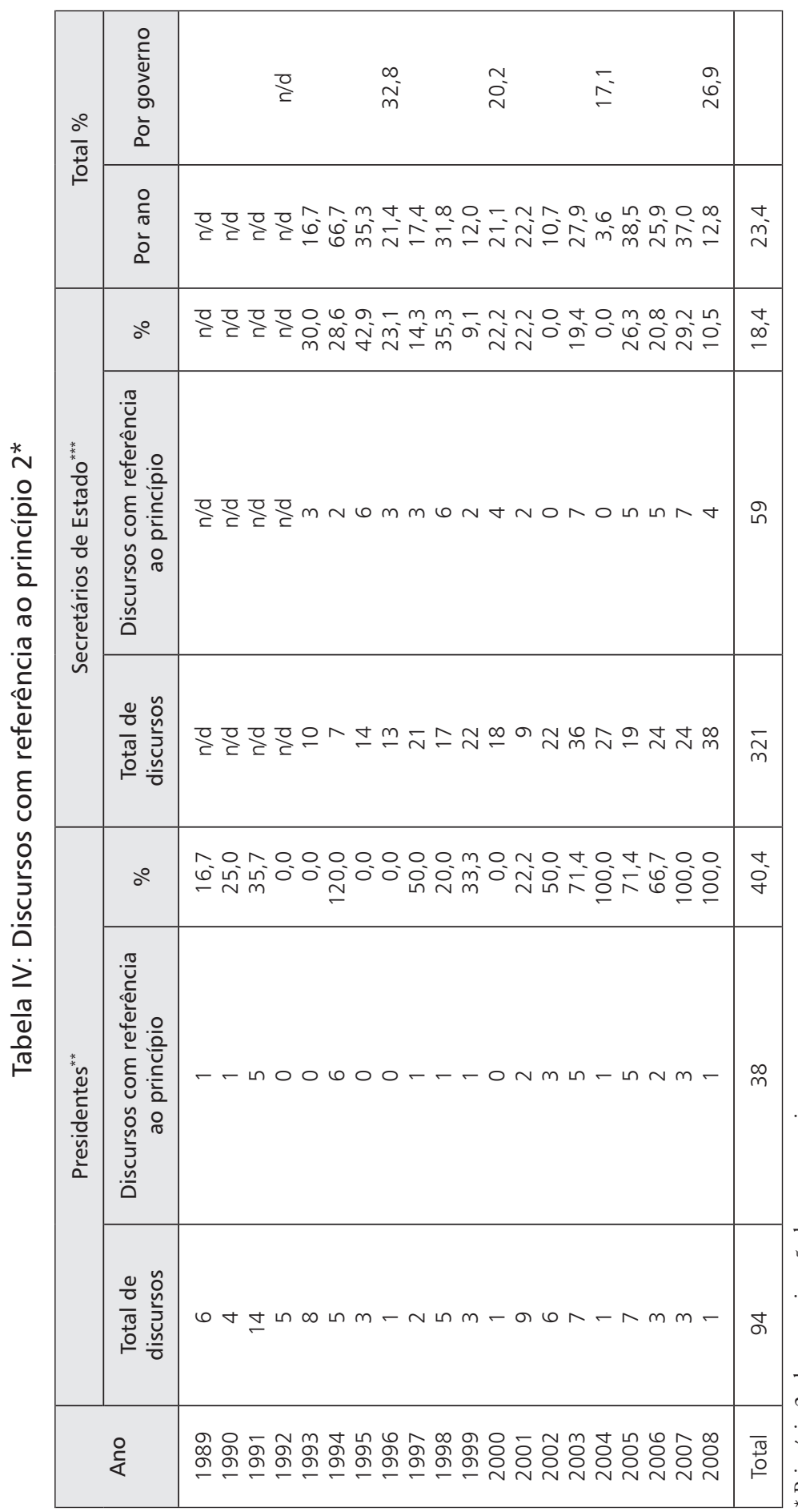




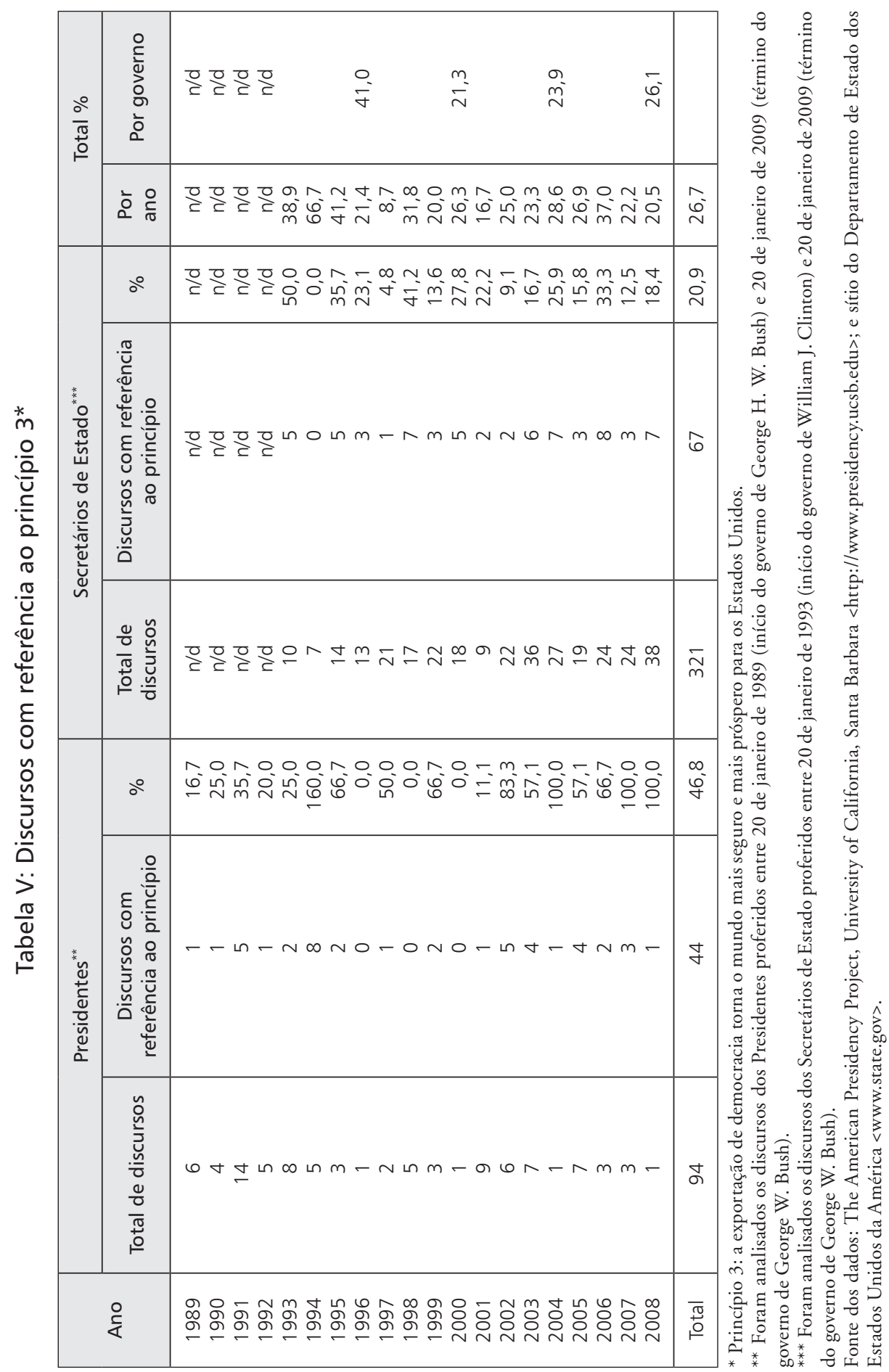




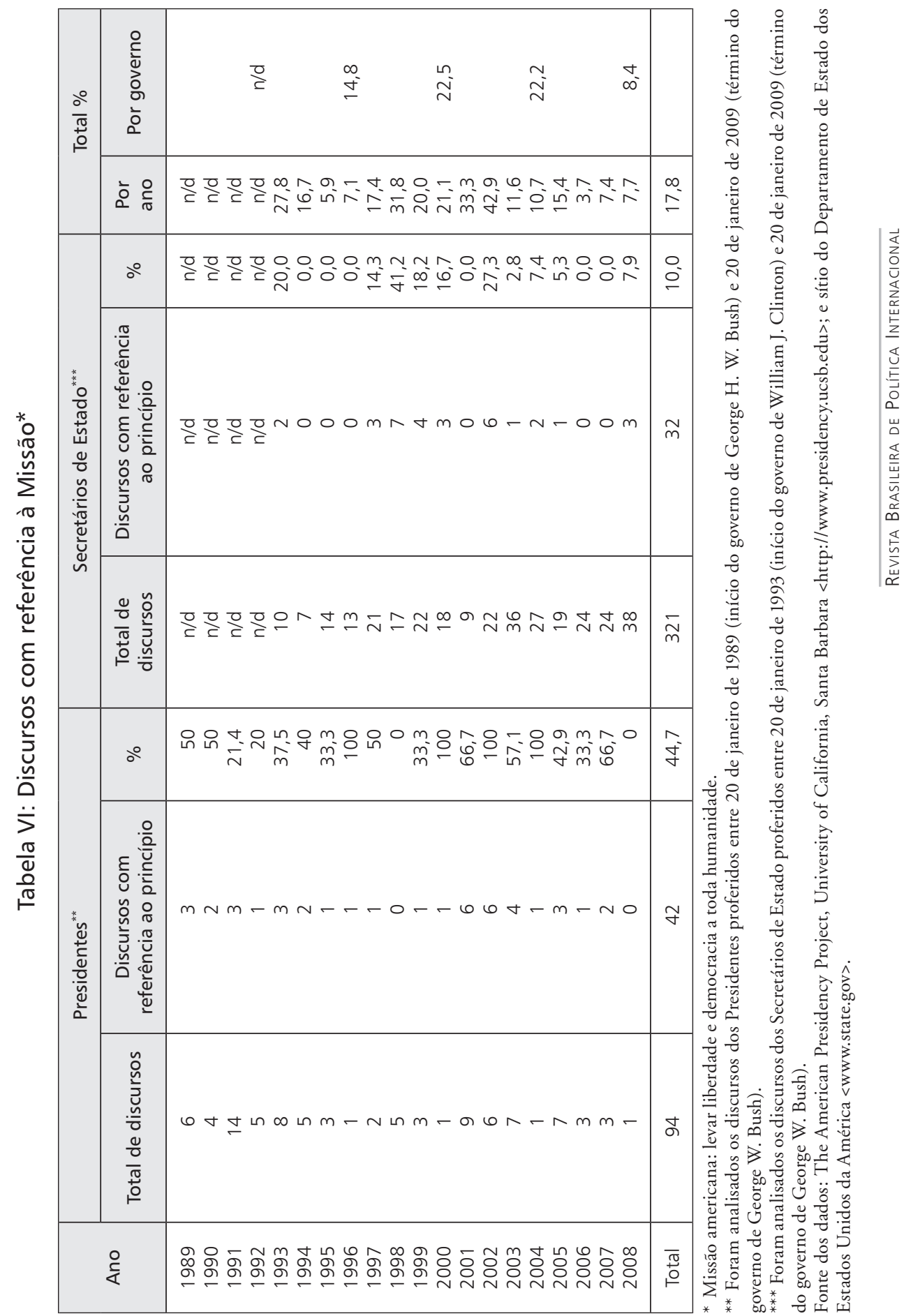


Figura I

Ocorrência das palavras "democracia" e "segurança" nos discursos dos Presidentes dos EUA, 1989-2008

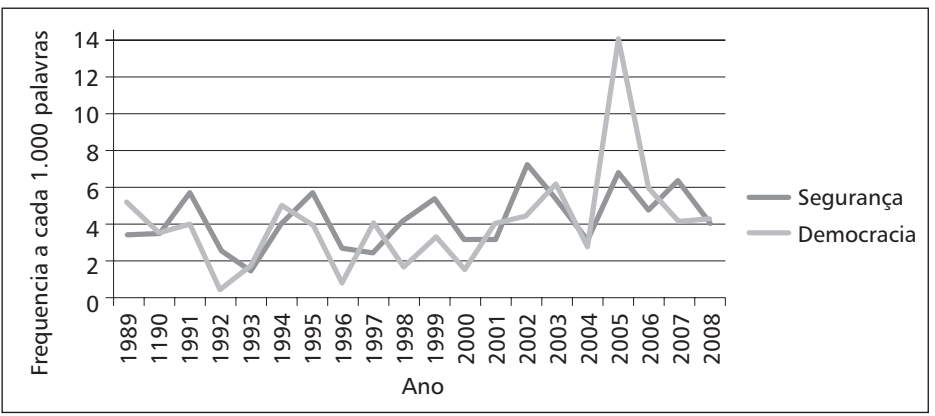

Figura II

Ocorrência das palavras "democracia" e "segurança" nos discursos dos Secretários de Estado dos EUA, 1989-2008

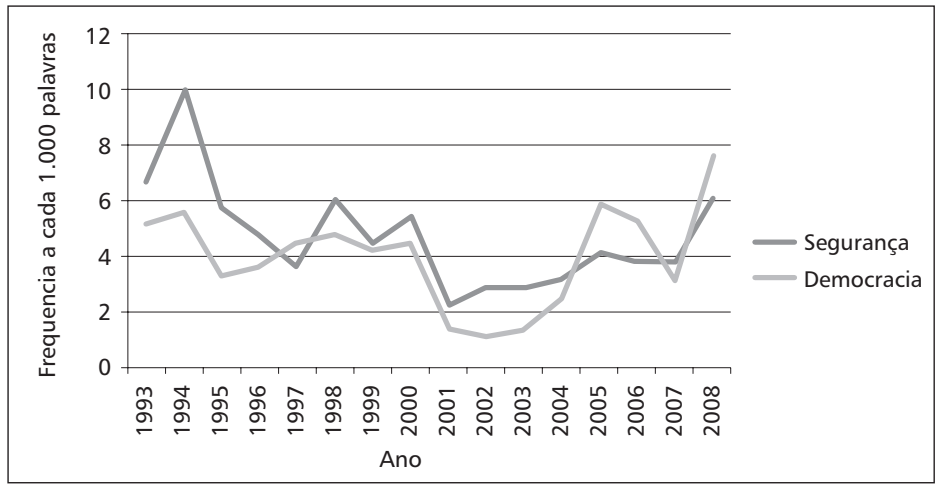

Figura III

Discursos dos Presidentes e Secretários de Estado com referência ao princípio 1, por governos, 1993-2008

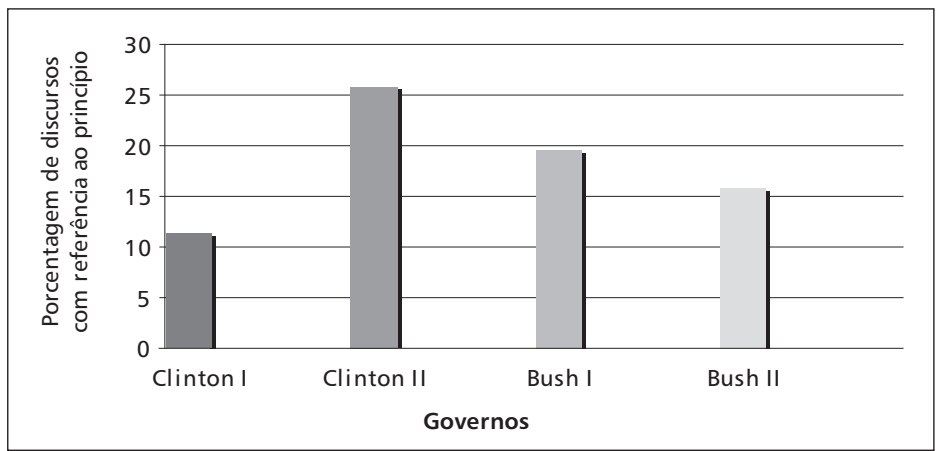


Figura IV

Discursos dos Presidentes e Secretários de Estado com referência ao princípio 2, por governos, 1993-2008

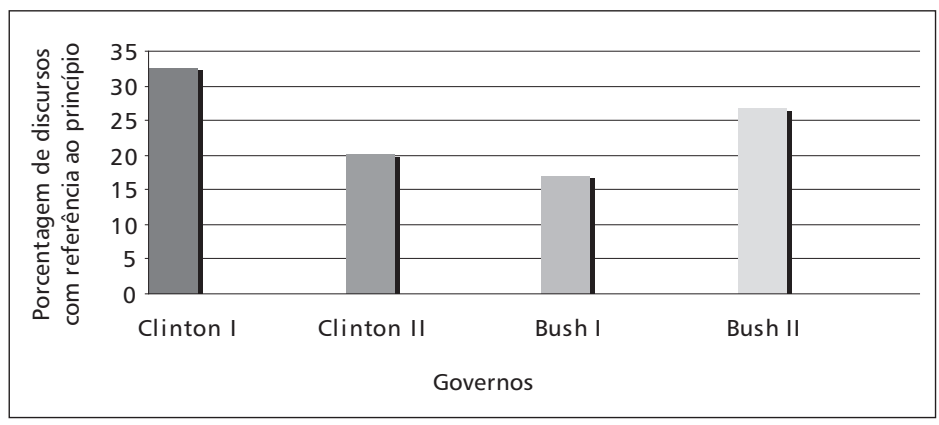

Figura $\mathrm{V}$

Discursos dos Presidentes e Secretários de Estado com referência ao princípio 3, por governos, 1993-2008

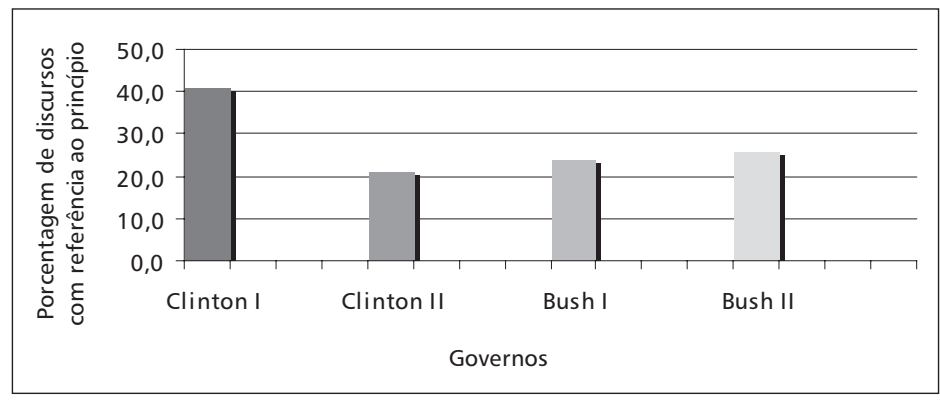

Figura VI

Discursos dos Presidentes e Secretários de Estado com referência à Missão, por governos, 1993-2008

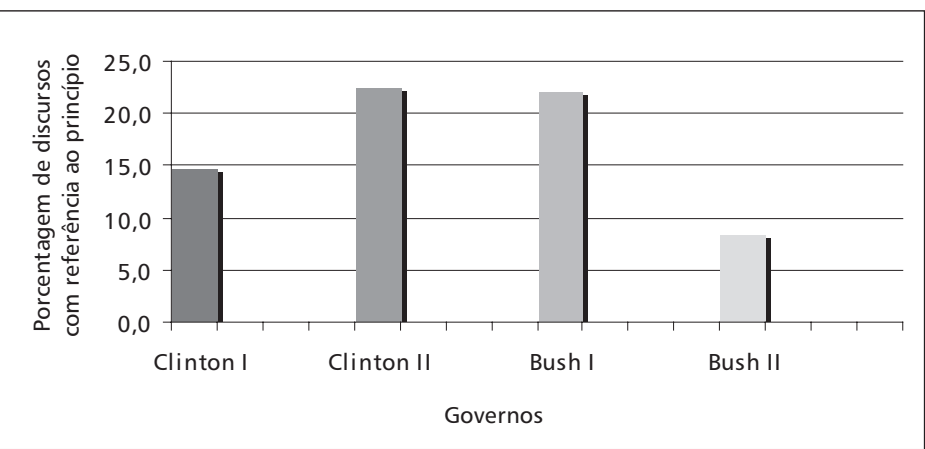




\section{Referências bibliográficas}

CAMERON, Fraser. US Foreign Policy after the Cold War. London and New York: Routledge, $2^{\text {nd }}$ edition, 2005.

CASTRO SANTOS, Maria Helena. O Processo de Democratização da Terceira Onda de Democracia: quanto pesam as variáveis externas?. Boletim Meridiano 47, No. 115, 2010, p. 15-18.

CASTRO SANTOS, Maria Helena. O Papel dos Estados Unidos na Nova Ordem Internacional e as Intervenções Militares Americanas no Pós-Guerra Fria: que lugar ocupa aí a democracia? Boletim Meridiano 47, no 117, 2010b, p.18 a 22.

DIAMOND, Larry (1992). Promoting Democracy. Foreign Policy, no 87, Summer, 1992, p. $25-47.98$

FARER, Tom (ed.). Beyond Sovereignty: collectively defending democracy in the Americas. Baltimore and London: The Johns Hopkins University Press, 1996.

FUKUYAMA, Francis. The End of History. The National Interest, 16 Summer, 1989.

FUKUYAMA, Francis. The End of the History and the Last Man. New York: Avon Books, 1992.

HARTZ, Louis. The Liberal Tradition in America - an interpretation of American political thought since the revolution. New York: Harcourt, Brace \& World, 1955.

HOOK, Steven and John Spanier. American Foreign Policy since World War II. Washington D. C.: CQ Press, 2007.

HUNTINGTON, Samuel. The Third Wave: democratization in the late twentieth century. Norman and London: University of Oklahoma Press, 1991.

HUNTINGTON, Samuel. The Clash of Civilizations and the Remaking of World Order. New York: Simon \& Schuster, 1996.

JOWITT, Ken. New World Disorder: the leninist extinction. Berkeley, Los Angeles and London: University of California Press, 1992.

KEGLEY, Charles \& HERMANN, Margaret. How Democracies Use Intervention: A Neglected Dimension in Studies of the Democratic Peace. Journal of Peace Research, vol. 33, no 3, 1996, p. 309-322.

LAYNE, Christopher. Kant or Cant: the Myth of the Democratic Peace. International Security, vol.19, no 2, 1994, p. 5-49.

MEARSHEIMER, John J. Back to the Future: Instability in Europe After the Cold War. International Security, vol.15, no1, 1990, pp. 5-56.

OWEN, John M. Democracy, Realistically. The National Interest, Spring, 2006.

PACKENHAM, Robert. Liberal America and the Third World. Princeton, NJ: Princeton University Press, 1973.

RUMMEL, RJ. Libertarianism and International Violence. Journal of Conflict Resolution, vol. 27, no 1, 1983, p. 27-71.

RUSSETT, Bruce. Grasping the Democratic Peace: Principles for a Post-Cold War World. Princeton: Princeton University Press, 1993. 
STARR, Harvey.Democracy and War: Choice, Learning and Security Communities. Journal of Peace Research, vol. 29, no 2, 1992, p. 207-213.

Recebido em 2 de outubro 2009

Aprovado em 17 de maio de 2010

\section{Resumo}

O artigo analisa os pilares da política externa americana no pós-guerra fria, mirando o lugar que ai ocupa democracia e sua relação com segurança. Busca-se mais especificamente as bases da doutrina da política externa que justificam a exportação de democracia pelo uso da força. Utilizou-se a análise de conteúdo quantitativa e qualitativa de 415 discursos dos Presidentes e Secretários de Estado entre 1989 e 2008.

\section{Abstract}

The article analyses the pillars of the American foreign policy in the post-cold war period, focusing on the importance democracy vis-à-vis security plays in it as well as their relationship. More specifically the work aims to define the bases of the doctrine of the foreign policy that justify exporting democracy by the use of force. It was used quantitative and qualitative content analysis of 414 speeches of the Presidents and Secretaries of States in the period 1989-2008.

Palavras-chave: Política externa Americana; exportação de democracia; uso da força; pós-Guerra Fria.

Key-words: American foreign policy; exporting democracy; use of force; Post-cold war period. 